\title{
ANALISIS WACANA INTERAKSI KELAS BAHASA GURU DALAM PEMBELAJARAN BAHASA INDONESIA DI KELAS VII B SMPN 11 KOTA BENGKULU TAHUN AJARAN 2016/2017
}

\author{
Sakalia Wirma ${ }^{1}$, Suryadi ${ }^{2}$, dan Bambang Djunaidi ${ }^{3}$ \\ ${ }^{1,2,3}$ Program Studi Pendidikan Bahasa dan Sastra Indonesia \\ Jurusan Pendidikan Bahasa dan Seni \\ FKIP Universitas Bengkulu \\ shakalyawirma@gmail.com
}

\begin{abstract}
Abstrak
Tujuan penelitian ini adalah untuk mengetahui serta menganalisis wacana interaksi kelas bahasa guru dalam pembelajaran bahasa Indonesia di kelas VII B SMP Negeri 11 kota Bengkulu. Metode yang digunakan dalam penelitian ini adalah metode deskriptif kualitatif. Data dalam penelitian ini berupa tuturan bahasa guru yang digunakan ketika belajarmengajar di kelas dengan memperhatikan wacana interaksi kelas yang berupa transaksi, pertukaran, dan tindak. Teknik pengumpulan data menggunakan teknik rekaman. Teknik analisis data dalam penelitian ini dilakukan melalui langkah-langkah yaitu: (1) Pentranskripsian data, (2) Pengkodean data, (3) Pengklasifikasian data, (4) Penginterpretasian data, dan (5) Penyimpulan data. Pemeriksaan keabsahan data dilakukan dengan member check atau mengecek ke responden. Hasil penelitian yang ditemukan adalah wacana interaksi kelas yang berupa transaksi, pertukaran, dan tindak. Pada wacana transaksi, ditemukan tiga jenis transaksi, yaitu transaksi penerangan, transaksi pengarahan, dan transaksi pancingan. Pada wacana pertukaran, ditemukan dua jenis pertukaran, yaitu pertukaran batas dan pertukaran pengajaran. Pada wacana tindak, ditemukan lima belas jenis tindak, yaitu penanda, pengantar, pemancingan, pemeriksaan, direktif, informatif, dorongan, petunjuk, isyarat, penunjukan, pengakuan, jawaban, persetujuan, metastatement, dan kesimpulan.
\end{abstract}

Kata Kunci: Analisis wacana interaksi, pembelajaran.

\begin{abstract}
Abstrack
The purpose of this research is to know and analyze the discourse of teacher language language interaction in learning Indonesian language in class VII B SMP Negeri 11 Bengkulu city. The method used in this research is descriptive qualitative method. The data in this research is teacher speech which is used when teaching and learning in class by paying attention to discourse of class interaction in the form of transaction, exchange, and action. Data collection techniques using recording techniques. Data analysis technique in this research is done through the steps are: (1) Pentranskripsian data, (2) Data encoding, (3) Data classification, (4) Interpretation of data, and (5) Data inference. Inspection of data validity is done by member check or check to responder. The result of the research is discourse of class interaction in the form of transaction, exchange, and action. In the discourse of transactions, found three types of transactions, namely lighting transactions, directive transactions, and inducement transactions. In the exchange discourse, two types of exchanges are found, namely the exchange of limits and the exchange of instruction. In the discourse of action, found fifteen types of action, namely marker, introduction, fishing,
\end{abstract}


inspection, directive, informative, encouragement, guidance, cue, designation, recognition, answer, approval, metastatement, and conclusions.

\section{Keywords: Interaction discourse, learning.}

\section{PENDAHULUAN}

Bahasa merupakan alat komunikasi yang disampaikan oleh pembicara kepada pendengar. Jika komunikasi yang dilakukan tersebut baik, maka pesan yang akan disampaikan juga akan mudah dipahami oleh pendengar, begitupun sebaliknya. Sebagai alat komunikasi, bahasa harus mampu menampung perasaan dan pikiran pemakainya serta mampu menimbulkan saling mengerti antara penutur dan petutur.

Selain itu, bahasa sebagai alat berkomunikasi juga untuk menyampaikan maksud dan tujuan tertentu serta mengekspresikan diri antara satu dengan lainnya. Jadi, bahasa memegang peranan penting dalam kehidupan karena bahasa merupakan sarana untuk berinteraksi dengan orang lain. Hal ini perlu diperhatikan, apalagi oleh para guru bahasa khususnya dan para guru bidang studi lainnya. Maka selain guru, sekolah juga dapat menjadi wadah yang mendukungnya.

Sekolah sebagai wadah pendidikan formal juga terdapat di dalamnya beberapa pendukung terlaksananya proses pembelajaran yaitu, adanya guru, siswa, sarana dan prasarana, dan pendukung lainnya. Dengan kondisi seperti itu sekolah dapat dikatakan sebagai miniatur masyarakat kecil sehingga di dalamnya terjadi interaksi antara guru dengan guru, guru dengan siswa, serta siswa dengan siswa. Dari interaksi tersebut, maka terjadilah proses belajar-mengajar.

Terlepas dari itu semua, faktor yang paling penting dalam terlaksananya proses belajar-mengajar adalah guru. Guru adalah orang yang mengatur dan melaksanakan jalannya proses belajar-mengajar di kelas.
Guru harus mampu menggunakan bahasa agar dapat menjalin komunikasi yang baik dengan siswanya. Jika bahasa guru tersebut lugas dan jelas, serta tidak berbelit-belit, maka pesan atau materi yang disampaikan dapat dipahami oleh siswanya. Untuk itu, guru juga harus memperhatikan seperti apa tingkat kemampuan siswanya, sehingga materi yang disampaikan dapat dikuasai oleh siswa tersebut. Dengan demikian, bahasa guru haruslah mampu dipahami oleh siswanya.

Bahasa guru yang mampu dipahami oleh siswa dapat memperlancar jalannya proses belajar-mengajar di kelas. Proses tersebut terdiri dari beberapa struktur wacana yaitu dari pembukaan pembelajaran, penjelasan materi, serta penutup pembelajaran. Maka dari struktur tersebut di dalamnya terdapat beberapa hal penting yang menurut Ramirez (dalam Rani, 2004:62) menyatakan bahwa wacana interaksi kelas adalah tataran urutan interaksi antara guru dan siswa di dalam proses belajar mengajar yaitu adanya transaksi-pertukaran-tindak-gerak. Faktor ini kurang mendapat perhatian orang dalam upaya mencari penyebab kurang berhasilnya proses pembelajaran tersebut.

Adapun permasalahan dalam penelitian ini yaitu bagaimanakah wacana interaksi kelas bahasa guru dalam pembelajaran bahasa Indonesia di kelas VII B SMP Negeri 11 kota Bengkulu. Namun penelitian ini dibatasi pada bahasa guru secara lisan mata pelajaran bahasa Indonesia pada saat proses belajar mengajar berlangsung khususnya di kelas VII B SMP Negeri 11 Kota Bengkulu berdasarkan wacana interaksi kelas yang berupa transaksi, pertukaran dan tindak. 
Setelah itu menghasilkan tujuan yaitu untuk mengetahui serta menganalisis wacana interaksi kelas bahasa guru dalam pembelajaran bahasa Indonesia di kelas VII B SMP Negeri 11 kota Bengkulu.

Adapun harapan akan memberikan manfaat dari hasil penelitian ini yaitu dapat menambah atau memperkaya wawasan serta pengetahuan mengenai analisis wacana interaksi kelas. Kemudian juga dapat dijadikan bahan informasi tambahan bagi peneliti yang lain yang tertarik untuk meneliti lebih jauh bidang ini.

Secara ringkas, wacana interaksi kelas merupakan serangkaian interaksi yang berupa ujaran atau tuturan yang terjadi antara guru dan siswa dalam proses belajar mengajar di kelas. Dalam wacana interaksi kelas ini terdapat beberapa tahap proses pembelajaran diantaranya membuka, menjelaskan, dan menutup pembelajaran.

Adapun struktur wacana interaksi kelas dalam penelitian ini, yaitu transaksi, pertukaran dan tindak. Transaksi merupakan proses interaksi yang berupa kesepakatan antara guru dan siswa ketika kegiatan belajar mengajar akan berlangsung. Pertukaran merupakan proses bergantinya suatu topik pembelajaran dalam proses belajar mengajar. Tindak merupakan suatu ujaran yang mengandung tindakan dalam komunikasi yang mempertimbangkan aspek situasi tutur dalam proses belajar mengajar berlangsung.

\section{METODE}

Metode penelitian yang digunakan dalam penelitian ini adalah metode deskriptif kualitatif. Penggunaan metode ini untuk mendeskripsikan bahasa yang digunakan oleh guru Bahasa Indonesia ketika berinteraksi di kelas VII B SMP Negeri 11 Kota Bengkulu berdasarkan pada struktur wacana interaksi kelas.

Penelitian ini dilaksanakan dari tanggal 27 Februari 2017 sampai dengan tanggal
27 Maret 2017 di SMP Negeri 11 kota Bengkulu yang berlokasi di Jalan Bandar Raya Rawa Makmur Permai Bengkulu.

Sumber data dalam penelitian ini adalah interaksi antara guru dan siswa pada saat proses belajar-mengajar di kelas VII B SMP Negeri 11 kota Bengkulu dan guru yang mengajar di kelas tersebut bernama Hafrisnaliza, sedangkan data dalam penelitian ini adalah tuturan bahasa guru yang digunakan ketika belajarmengajar di kelas dengan memperhatikan wacana interaksi kelas yang berupa transaksi, pertukaran dan tindak.

Teknik yang dilakukan dalam penelitian ini dilakukan dalam satu tahap, yaitu teknik rekaman. Rekaman yang dimaksud dalam hal ini adalah rekaman yang menggunakan alat elektronik berupa kamera digital yaitu "Fuji Kamera FinePix S4200" dengan tipe kamera DSLR Like. Alat ini digunakan untuk merekam bahasa guru ketika berinteraksi di kelas VII B SMP Negeri 11 kota Bengkulu.

Kemudian data yang telah terkumpul dianalisis secara kualitatif dengan langkahlangkah sebagai berikut:

a. Pentranskripsian Data

Data yang berupa bahasa lisan guru dalam proses belajar mengajar yang diperoleh melalui rekaman, kemudian ditraskripsikan dalam bentuk tulisan atau dalam bentuk wacana dialog.

b. Pengkodean Data

Setelah data ditranskripsikan, peneliti memberi kode disetiap ujaran baik itu ujaran dari guru maupun dari siswa. Pengkodean dilakukan dengan cara memberi nomor untuk setiap ujaran guru guna memudahkan peneliti dalam menganalisis data.

c. Pengklasifikasian Data

Data yang sudah ditranskripsikan dan di beri kode, selanjutnya dilakukan pengklasifikasian dari setiap ujaran yang ada untuk dikelompokkan sesuai struktur wacana interaksi kelas, yaitu 
pembukaan (opening), jawaban (answering), dan lanjutan (follow-up).

d. Penginterpretasi atau Penafsiran Data

Setelah data diklasifikasikan dan dianalisis, maka langkah selanjutnya adalah melakukan interpretasi atau penafsiran terhadap data tersebut. Hal ini dilakukan untuk mendeskripsikan atau mengungkapkan serta mencoba menggali sesuatu yang terdapat pada bahasa guru melalui wacana interaksi kelas yang dilakukan secara mendalam oleh peneliti.

e. Penyimpulan Data

Setelah data tersebut dianalisis, langkah terakhir adalah melakukan penyimpulan dari analisis yang telah dilakukan.

Setelah data didapatkan, maka langkah selanjutnya yaitu melakukan pemeriksaan keabsahan data dengan member check atau mengecek ke responden. Menurut Sugiyono (2006: 375) tujuan mengadakan member check adalah agar informasi yang telah diperoleh dan yang akan digunakan dalam penulisan laporan sesuai dengan apa yang dimaksud oleh informan. Penelitian ini dilakukan dengan memeriksakan keabsahan dengan cara meminta terlebih dahulu atau menanyakan kesetujuan atau ketidaksetujuan guru yang dijadikan subjek penelitian atas data yang akan diperoleh. Kemudian apabila setuju maka peneliti menyerahkan hasil transkripsi data kepada guru untuk diperiksa dan diperbaiki jika diperlukan.

\section{HASIL DAN PEMBAHASAN}

Penelitian ini dilakukan di kelas VII B SMP Negeri 11 kota Bengkulu sebanyak 4 kali pertemuan dengan guru yang mengajar yaitu Ibu Hafrisnaliza. Data penelitian ini berupa wacana interaksi kelas bahasa guru dalam pembelajaran bahasa Indonesia di kelas. Adapun wacana interaksi kelas menurut Sinclair dan
Coulthard dalam Tarigan (1987: 123) ada empat bagian yaitu transaksi, pertukaran, gerakan dan tindak.

Berdasarkan analisis data yang diperoleh, guru menggunakan bahasa Indonesia yang berfungsi sebagai bahasa pengantar keilmuan atau pendidikan. Dalam kegiatan belajar mengajar tersebut, ada faktor utama yang harus diketahui oleh guru yaitu interaksi belajar mengajar.

Kegiatan interaksi dalam pembelajaran antara guru dan siswa dapat dikaji dengan menggunakan pendekatan analisis wacana. Pada struktur wacana interaksi kelas berdasarkan ruang lingkup penelitian ini berupa transaksi, pertukaran, dan tindak. Hasil analisis data akan disajikan sebagai berikut.

\section{Transaksi pada Proses Pembelajaran di Kelas VII B SMP Negeri 11 Kota Bengkulu}

Transaksi merupakan proses interaksi yang berupa kesepakatan antara guru dan siswa ketika kegiatan belajar mengajar akan berlangsung. Transaksi biasanya di mulai dengan pertukaran persiapan dan berakhir dengan pertukaran akhir (Tarigan, 1987: 162). Pertukaran tengah (medial) pertama dalam suatu transaksi secara normal akan diseleksi dari tiga tipe utama pertukaran bebas, yaitu inform (menerangkan), direct (mengarahkan), dan elicit (memancing). Pada hasil penelitian ditemukan contoh tuturan transaksi yang berupa transaksi penerangan, transaksi pengarahan, dan transaksi pancingan.

Data transaksi penerangan yang terdapat pada data lampiran 3 Klasifikasi Data A.1 yaitu (30)G : Ini rumah yang di cat biru, ini bentuk mati. Kemudian, rumah ini bisa ndak kita deskripsikan? Ini benda mati ya nak, kita deskripsikan. Kalian bisa deskipsikan dari segi apanya? Kalau dari bentuknya berarti yang nomor empat (menunjuk ke papan tulis). Tetapi kalau dari letaknya sama seperti yang ini 
(menunjuk ke papan tulis lagi). Data tuturan yang berisi transaksi penerangan ditemukan oleh Susanti (2011) dengan konteks yang berbeda (Wacana Kelas Bahasa Guru dalam Pembelajaran di TK Perwanida Argamakmur Bengkulu Utara).

Data transaksi pengarahan yang terdapat pada data lampiran 3 Kalsifikasi Data A.2 yaitu (127) G : Sekarang, (menenangkan siswa-siswa yang ribut) sekarang dengan teman sebangku ya, kalian mencari paling tidak sepuluh kata dasar yang awalannya $P, K, T, S$. Contohnya pesona, menjadi mempesona. Dengan teman sebangku, mulai ya! Dalam sepuluh kata itu harus ada kata dasar awalannya $P, K, T, S$. Data tuturan yang berisi transaksi pengarahan ditemukan oleh Susanti (2011) dengan konteks berbeda (Wacana Kelas Bahasa Guru dalam Pembelajaran di TK Perwanida Argamakmur Bengkulu Utara).

Data transaksi pancingan yang terdapat pada lampiran 3 Klasifikasi Data A.3, yaitu (24) G : Hah, betul apa tidak? Coba kalian perhatikan ya! (menunjuk papan tulis) Kalian perhatikan yang empat ini! Jika jawaban Aldi seperti ini, yang betul mana? Data tuturan yang berisi transaksi pancingan ditemukan oleh Susanti (2011) dengan konteks berbeda (Wacana Kelas Bahasa Guru dalam Pembelajaran di TK Perwanida Argamakmur Bengkulu Utara).

Berdasarkan hasil penelitian baik dalam penelitian ini ataupun penelitian oleh Susanti (2011) masing-masing menemukan struktur transaksi yang berupa transaksi penerangan, transaksi pengarahan, dan transaksi pancingan. Struktur transaksi dalam interaksi kelas ini terlihat dalam ujaran guru. Hal ini penting karena di dalam proses belajar mengajar, guru haruslah memberikan penerangan mengenai materi pelajaran yang akan dipelajari oleh siswa. Selain itu, guru juga harus memberikan pengarahan, agar siswa paham dan mengerti akan tugas yang harus mereka kerjakan dalam proses belajar mengajar. Kemudian, guru juga harus memberikan pancingan berupa pertanyaan agar siswa dapat lebih aktif dalam kegiatan belajar mengajar di kelas.

\section{Pertukaran pada Proses Pembelajaran di Kelas VII B SMP Negeri 11 Kota Bengkulu}

Pertukaran merupakan proses bergantinya suatu topik atau pembicaran dalam proses belajar mengajar. Ada tiga bagian pertukaran yang harus diperhatikan, yaitu pertukaran awal, pertukaran tengah, dan pertukaran akhir. Pertukaran awal biasanya berada pada bagian pembukaan pembelajaran, pertukaran tengah biasanya pada bagian inti pembelajaran, dan pertukaran akhir biasanya berada pada bagian penutup pembelajaran. Pakar wacana lisan Deidre Burton dalam Tarigan (1987: 152) membedakan dua jenis pertukaran atau exchanges, yaitu: pertukaran batas dan pertukaran pengajaran. Pada hasil penelitian, peneliti menemukan kedua jenis pertukaran ini.

Data pertukaran batas dalam proses pembelajaran yang terdapat pada data lampiran 3 Klasifikasi Data B.1, yaitu (10) G : Ya (mengambil spidol yang diberikan oleh salah satu siswa). Sekarang kita belajar ya..... Data tuturan yang berisi pertukaran batas ditemukan juga oleh Susanti (2011) dengan konteks yang berbeda (Wacana Kelas Bahasa Guru dalam Pembelajaran di TK Perwanida Argamakmur Bengkulu Utara).

Data pertukaran pengajaran dalam proses pembelajaran yang terdapat pada data lampiran 3 Klasifikasi Data B.2, yaitu (97) $G$ : Hari ini, mama akan membandingkan kebahasaan teks deskriptif.... Data tuturan yang berisi pertukaran pengajaran ditemukan juga oleh Susanti (2011) dengan konteks berbeda (Wacana Kelas Bahasa Guru 
dalam Pembelajaran di TK Perwanida Argamakmur Bengkulu Utara).

Berdasarkan hasil penelitian ini dan penelitian oleh Susanti (2011) menemukan kedua jenis pertukaran ini. Pertukaran batas dalam proses pembelajaran ditemukan sebagai tanda atau batasan yang harus guru lakukan ketika pembelajaran akan berlangsung. Sedangkan pertukaran pengajaran ditemukan pada tuturan guru untuk menegtahui langkah-langkah yang harus guru lakukan ketika mengajar, misalnya langkah menerangkan, mengarahkan, memancing, dan memeriksa.

\section{Tindak pada Proses Pembelajaran di Kelas VII B SMP Negeri 11 Kota Bengkulu}

Tindak merupakan suatu ujaran yang mengandung tindakan dalam komunikasi yang mempertimbangkan aspek situasi tutur dalam proses belajar mengajar berlangsung. Sinclair dan Coulthard (1978) dalam Tarigan (1987: 125) misalnya membedakan 22 jenis tindak. Namun dalam penelitian ini yang ditemukan hanya 15 tindak yaitu, penanda yang ditandai dengan adanya kata "ya, sekarang, kemarin, nah, kemudian", pengantar yang ditandai dengan adanya pengantar yang bertujuan menyampaikan suatu informasi, pemancingan yang ditandai dengan adanya pertanyaan dari guru, pemeriksaan yang ditandai dengan pertanyaan sudah atau siap, direktif yang ditandai dengan adanya perintah dari guru, informatif yang ditandai dengan pernyataan yang berupa informasi, dorongan yang ditandai dengan adanya pernyataan 'ayo, selanjutnya, kalian bisa', petunjuk ditandai dengan adanya informasi untuk menolong siswa mengerjakan tugas, isyarat ditandai dengan cara tunjuk tangan, penunjukan ditandai dengan kata 'siapa, siapa lagi, menunjuk nama siswa', pengakuan yang ditandai dengan pernyataan 'iya, betul', jawaban ditandai dengan pengulangan jawaban siswa, persetujuan berupa pernyataan 'betul', metastatement yang ditandai dengan pernyataan yang memberikan informasi untuk melakukan tugas selanjutnya, dan kesimpulan yang ditandai dengan kata 'maka dan jadi'. Sedangkan 7 jenis tindak yang tidak ditemukan dalam ujaran guru ketika proses belajar mengajar, yaitu tawaran, reaksi, evaluasi atau penilaian, tekanan diam, putaran, komentar dan sampingan.

Sedangkan penelitian lain oleh Susanti (2011) menemukan struktur tindak yaitu 15 jenis tindak, diantaranya berupa penanda ditandai dengan adanya kata "baik, yah, nah", pengantar ditandai dengan adanya awal permulaan yang harus guru persiapkan sebelum mengajar, pemancingan ditandai dengan adanya pertanyaan dan siswa harus meresponsnya, pemeriksaan ditandai dengan kata "sudah dan selesai", direktif ditandai dengan kata perintah dari guru, informatif ditandai dengan adanya "penyampaian informasi baik untuk memahami penjelasan pembelajaran atau mengamankan situasi kelas", dorongan ditandai dengan kata "teruskan, lanjutkan", petunjuk ditandai dengan perintah untuk mengerjakan suatu tugas, isyarat ditandai dengan kata "tunjuk tangan, acungkan tangan", penunjukan ditandai dengan kata "kamu, siapa ayo, menyebut nama siswa", pengakuan ditandai dengan kata "oke, ya, benar, dan betul", jawaban ditandai dengan mengacungkan dua jempol dan mengernyitkan kening, reaksi ditandai dengan guru mengacungkan dua jempol, metastatement ditandai dengan penjelasan guru tentang suatu pernyataan yang mengacu pada kejadian yang akan terjadi, dan kesimpulan ditandai dengan menyimpulkan materi pembelajaran di akhir pembelajaran. Akan tetapi, ia juga tidak menemukan 7 jenis tindak, yaitu 
komentar, tekanan diam, persetujuan, evaluasi, putaran, tawaran dan sampingan pada data.

Berdasarkan hasil penelitian ini dan penelitian oleh Susanti (2011), ada 6 jenis tindak yang tidak ditemukan dalam tuturan guru, yaitu tindak komentar, tekanan diam, evaluasi, putaran, tawaran, dan sampingan. Untuk itu, perlu dilakukan penelitian secara mendalam mengenai ujaran yang mengandung tindakan dalam komunikasi ini yang mempertimbangkan aspek situasi tutur yang tidak ditemukan dalam penelitian ini. Bisa dengan cara memperbanyak data atau dengan memberikan perbandingan pada subjek yang berbeda seperti pelakuan pada dua guru atau lebih dalam kelas yang sama.

\section{PENUTUP}

\section{Kesimpulan}

Data penelitian ini berupa wacana interaksi kelas bahasa guru dalam pembelajaran bahasa Indonesia di kelas VII B SMP Negeri 11 kota Bengkulu. Berdasarkan hasil analisis yang diperoleh, guru menggunakan bahasa Indonesia yang berfungsi sebagai bahasa pengantar keilmuan atau pendidikan. Dalam kegiatan belajar mengajar tersebut, ada faktor utama yang harus diketahui oleh guru yaitu interaksi antara guru dan siswa. Adapun interaksi yang dimaksud adalah analisis wacana interaksi kelas berdasarkan ruang lingkup penelitian yang meliputi transaksi, pertukaran, dan tindak. Adapun simpulan masing-masing wacana interaksi kelas tersebut sebagai berikut.

a. Transaksi yang ditemukan dalam penelitian ini terbagi menjadi 3 jenis, yaitu transaksi penerangan, transaksi pengarahan, dan transaksi pancingan. Ketiga transaksi tersebut telah dilakukan oleh guru. Transaksi penerangan yaitu guru memberikan penerangan kepada siswa akan materi yang akan dipelajari. Contohnya yaitu
(30)G : Ini rumah yang di cat biru, ini bentuk mati. Kemudian, rumah ini bisa ndak kita deskripsikan? Ini benda mati ya nak, kita deskripsikan. Kalian bisa deskipsikan dari segi apanya? Kalau dari bentuknya berarti yang nomor empat (menunjuk ke papan tulis). Tetapi kalau dari letaknya sama seperti yang ini (menunjuk ke papan tulis lagi). (A.1.(1).(21)). Transaksi pengarahan yaitu guru memberikan pengarahan berupa penyampaian petunjuk untuk melakukan tugas yang telah diberikan oleh guru. Contohnya (127) G : Sekarang, (menenangkan siswa-siswa yang ribut) sekarang dengan teman sebangku ya, kalian mencari paling tidak sepuluh kata dasar yang awalannya $P, K, T$, S. Contohnya pesona, menjadi mempesona. Dengan teman sebangku, mulai ya! Dalam sepuluh kata itu harus ada kata dasar awalannya P, K, T, S. (A.2.(2).(120)). Transaksi pancingan yaitu guru memancing siswa dengan pertanyaanpertanyaan yang berkelanjutan. Pertanyaan tersebut membuat siswa tertarik untuk memperhatikan penjelasan selanjutnya. Contohnya (24) $G$ : Hah, betul apa tidak? Coba kalian perhatikan ya! (menunjuk papan tulis) Kalian perhatikan yang empat ini! Jika jawaban Aldi seperti ini, yang betul mana? (A.3.(2).(15)).

b. Pertukaran yang ditemukan dalam penelitian ini terbagi menjadi 2 bagian, yaitu pertukaran batas dan pertukaran pengajaran. Pertukaran batas dilakukan oleh guru untuk mengetahui batasan guru memulai dan mengakhiri pelajaran. Contohnya yaitu (10) $G: Y a$ (mengambil spidol yang diberikan oleh salah satu siswa). Sekarang kita belajar ya. Satu orang tidak hadir karna sakit ya nak ya! Kemarin, kemarin (memberi kode supaya siswa tidak ribut) kemarin kalian sudah belajar teks deskripsi 
(menulis di papan tulis) Sudah? Sudah belum? (B.1.(1).(1)). Kemudian pertukaran pengajaran yang merupakan batasan guru dalam menyampaikan materi pembelajaran di kelas. Contohnya (97) G : Hari ini, mama akan membandingkan kebahasaan teks deskriptif. Kebahasaannya. Sekarang buka buku kalian! Halaman berapa nak yang unsur kebahasaan? Kebahasaan? Apa saja yang perlu kita perhatikan? (B.2.(4).(88)).

C. Tindak yang ditemukan dalam penelitian ini sebanyak 15 jenis tindak yaitu, penanda yang ditandai dengan adanya kata "ya, sekarang, kemarin, nah, kemudian", pengantar yang ditandai dengan adanya pengantar yang bertujuan menyampaikan suatu informasi, pemancingan yang ditandai dengan adanya pertanyaan dari guru, pemeriksaan yang ditandai dengan pertanyaan sudah atau siap, direktif yang ditandai dengan adanya perintah dari guru, informatif yang ditandai dengan pernyataan yang berupa informasi, dorongan yang ditandai dengan adanya pernyataan 'ayo, selanjutnya, kalian bisa', petunjuk ditandai dengan adanya informasi untuk menolong siswa mengerjakan tugas, isyarat ditandai dengan cara tunjuk tangan, penunjukan ditandai dengan kata 'siapa, siapa lagi, menunjuk nama siswa', pengakuan yang ditandai dengan pernyataan 'iya, betul', jawaban, persetujuan berupa pernyataan 'betul', metastatement yang ditandai dengan pernyataan yang memberikan informasi untuk melakukan tugas selanjutnya, dan kesimpulan yang ditandai dengan kata 'maka dan jadi'.

\section{Saran}

Penelitian ini membahas mengenai wacana interkasi kelas pada proses pembelajaran di kelas VII B SMP Negeri 11 Kota Bengkulu. Diharapkan untuk penelitian selanjutnya dapat menemukan wacana tindak yang tidak ditemukan dalam penelitian ini, seperti tindak tawaran, tindak reaksi, tindak evaluasi, tindak tekanan diam, tindak putaran, tindak komentar dan tindak sampingan. Hal tersebut tidak ditemukan karena dapat disebabkan oleh beberapa hal antara lain jumlah data yang dikumpulkan kurang banyak atau kurang bervariasi dan jumlah guru yang diteliti tidak banyak. Untuk itu, penelitian selanjutnya juga dapat melakukan penelitian dengan memberikan perbandingan pada subjek yang berbeda seperti pelakuan pada dua guru atau lebih dalam kelas yang sama.

\section{DAFTAR PUSTAKA}

Rani, Abdul dkk. 2004. Analisis Wacana. Malang: Bayumedia Publishing.

Sugiyono. 2006. Metode Penelitian Pendidikan (Pendekatan Kuantitatif, Kualitatif, dan $R$ \& $D$. Bandung: Alfabeta.

Tarigan, Henry Guntur. 1987. Pengajaran Pragmatik. Bandung: ANGKASA.

Tarigan, Henry Guntur. 1987. Pengajaran Wacana. Bandung: ANGKASA. 